Steel, R. \& Walker, T. K. (1958). J. gen. Microbiol. 18, 369-376

\title{
Studies on the Antibacterial Activity of Certain Strains of Acetobacter
}

\author{
By R. STEEL AND T. K. WALKER \\ College of Science and Technology, Manchester
}

\begin{abstract}
SUMMARY: A turbidimetric assay is described for antibiotic substances produced by Acetobacter acetigenum, NCIB 8132, and Bacterium xylinoides, NCIB 4940, based on the amount of inhibition of growth of a celluloseless mutant. Yield of antibiotic from each organism was independent of the source of nitrogen in the medium, but varied markedly with the carbon source and was highest when the organisms were grown for 10 days at $30^{\circ}$ in a medium containing glucose $(9 \%, \mathrm{w} / \mathrm{v})$, Difco yeastextract $(0.5 \%, \mathrm{w} / \mathrm{v})$ and peptone (Evans, $3 \%, \mathrm{w} / \mathrm{v})$, in distilled water. Under these conditions growth of the assay organism was inhibited $50 \%$ by filtrate diluted $1 / 44$. The antibiotics were extremely alkali-labile being destroyed at $18^{\circ}$ in $2 \mathrm{~min}$. at pH 10. Activity of the filtrate from organism NCIB 8132 was not affected significantly by treatment with calcium carbonate, charcoal, cation- or anion-exchange resins, but was decreased by extraction at $\mathrm{pH} \mathrm{3.0}$ with $n$-butanol, chloroform or methyl ethyl ketone. Activity of filtrate of organism NCIB 4940 was decreased by treatment with charcoal, cation- or anion-exchange resins and by extraction at pH 3.0 with benzene, $n$-butanol, chloroform, diethyl ether, ethyl acetate or methyl ethyl ketone.
\end{abstract}

Previous work (Steel \& Walker, 1957a) on celluloseless mutants (organisms which do not produce extracellular cellulose) revealed that they occurred spontaneously in cellulose-producing cultures of certain Acetobacter species. It was later found that four cellulose-forming organisms representing three different species produced factors which inhibited the growth of mutant organisms (Steel \& Walker, 1957 b). Only one culture (Acetobacter acetigenum, NCIB 8132) was tested against Proteus vulgaris and it was found to be active against this organism. The present work was undertaken (i) to obtain an assay method for these antibiotics, (ii) to assess the effect of variations in the medium on their yield, and (iii) to study some of their properties.

\section{METHODS}

Cultures. The cellulose-forming bacteria studied were Acetobacter acetigenum, NCIB 8132, and Bacterium xylinoides, NCIB 4940. Proteus vulgaris, NCIB 67 , was tested as assay organism. These cultures were received from the National Collection of Industrial Bacteria, Teddington, Middlesex. The celluloseless mutants tested as assay organisms were obtained by methods described previously (Steel \& Walker, 1957 a). The cellulose-producing organisms were stored in malt-wort medium (Tosic \& Walker, 1946), whereas the others were kept on a medium $(\mathrm{pH} 7 \cdot 0)$ containing glucose $(3 \%, \mathrm{w} / \mathrm{v})$ and Difco yeastextract $(0.5 \%, w / v)$ in distilled water (hereafter, GYE medium). The use of these media was dictated by previous findings (Steel \& Walker, 1957a). 
Media composition. Media (of the composition given below and at $\mathrm{pH} \mathbf{7 \cdot 0}$ unless stated otherwise) were dispensed either in $150 \mathrm{ml}$. quantities in mould culture-flasks (Clayton et al. 1944) or in $50 \mathrm{ml}$. portions in $250 \mathrm{ml}$. conical flasks. After sterilization at $15 \mathrm{lb}$./sq.in. for $15 \mathrm{~min}$. they were inoculated by a sterile wire loop from a $48 \mathrm{hr}$. GYE culture of the appropriate organism and incubated at $30^{\circ}$.

Assay procedure. The following was selected as the standard assay method after preliminary experiments, described later, had been made. After passage of the culture medium through a Seitz filter to remove the bacteria, the filtrate was adjusted with sodium hydroxide to $\mathrm{pH} 6.0$ and the desired volume was dispensed in triplicate to nephelometer tubes previously randomized (Brownlee, 1949). The volume was made up to $6 \mathrm{ml}$. with assay medium ( $\mathrm{pH} \mathrm{6.0}$ ) consisting of glucose $(3 \%, \mathrm{w} / \mathrm{v})$, Difco Casamino acids $(0.5 \%, \mathrm{w} / \mathrm{v})$ and peptone (Evans, $0.5 \%, \mathrm{w} / \mathrm{v}$ ) in distilled water. Triplicate tubes of assay medium ( $6 \mathrm{ml}$.) containing no added filtrate were included as positive controls. The tubes were plugged with cotton wool, sterilized at $10 \mathrm{lb}$./sq.in. for $10 \mathrm{~min}$., then inoculated with one drop (c. $0.05 \mathrm{ml}$.) of a $24 \mathrm{hr}$. culture of a celluloseless mutant, designated as 8132-A2, grown in the assay medium. After incubation at $30^{\circ}$ for $24 \mathrm{hr}$. the turbidity was measured. These turbidity values were corrected by subtracting the reading given by the uninoculated media (blank). Then the percentage of growth inhibition (the parameter used in this paper to express antibiotic activity) was calculated from the expression

$$
\frac{\text { Turbidity of control - turbidity of test solution }}{\text { Turbidity of control }} \times 100 \text {. }
$$

The resulting value plotted on semi-logarithmic paper against culture dilutions showed a linear relationship (Fig. 1). The estimate of growth obtained in the control cultures gave a standard error among replicates which varied from 0 to $12 \%$ (average $5.8 \%$ ) from one experiment to another. In those instances where the variability among replicates was excessively large, the experiments were repeated. It was realized that the growth of the assay organism in media containing added filtrate might differ from that in control media not containing added filtrate because the media were not nutritionally equivalent, but this difficulty could not be circumvented. In those cases where a significant difference between treatments was not obvious from inspection of the data, the mean turbidity values were compared statistically (Br ownlee, 1949).

\section{RESULTS}

Preliminary assay experiments. Tests with an active culture filtrate of both organisms showed that sterilization at $10 \mathrm{lb} . / \mathrm{sq}$.in. for $15 \mathrm{~min}$. or passage through a Seitz filter or a membrane filter gave products all having the same potency. Clarification by Seitz filtration followed by heat sterilization was selected as the standard procedure for ease of handling a large number of solutions.

The $\mathrm{pH}$ during sterilization was found to be critical. At pH $7 \cdot 0$ or higher all 
activity appeared to be destroyed while media sterilized at $\mathrm{pH} 5 \cdot 0$ gave slow growth of the assay organism. Hence $\mathrm{pH} 6 \cdot 0$ was adopted in all subsequent work.

A celluloseless mutant designated 8132-A2 was found preferable as assay organism to the other mutants tested and to Proteus vulgaris, since it showed a uniform and slightly faster rate of growth.

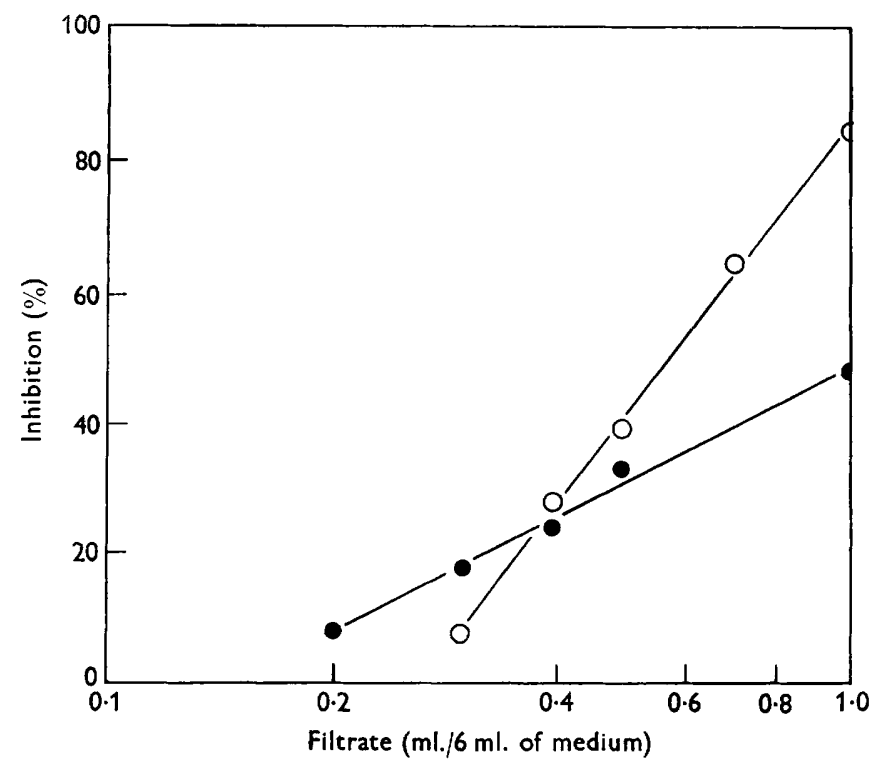

Fig. 1. Dose-response graphs. - , filtrate of Acetobacter acetigenum, NCIB 8132, grown in GYE medium; $\mathrm{O}_{-} \mathrm{O}$, filtrate of Bacterium xylinoides, NCIB 4940, grown in glucose $(6 \%, w / v)$, Oxoid soya-peptone $(3 \%, w / v)$ medium; filtrates assayed at 6 days.

\section{Some factors affecting the yield of antibiotics}

Nitrogen sources. The following compounds added primarily as sources of nitrogen, although they also contain carbon, were tested singly in a basal medium consisting of glucose $(3 \%, \mathrm{w} / \mathrm{v})$ in distilled water: Difco yeast-extract $(0.5 \%, w / v)$, Oxoid soya-peptone $(3 \%, w / v)$, cornsteep liquor $(2 \%, w / v)$ and Evans's peptone $(3$ and $6 \%, w / v)$. Cornsteep liquor and Evans's peptone were also tested in combination with Difco yeast-extract. After 10 days' incubation organisms NCIB 8132 and NCIB 4940 gave essentially similar potencies on all media tested.

Carbon sources. With organism NCIB 8132 in a basal medium consisting of Difco yeast-extract $(0.5 \%, \mathrm{w} / \mathrm{v})$ and Evans's peptone $(2 \%, \mathrm{w} / \mathrm{v})$ in distilled water, the supplementary carbon sources listed in Table 1, when added at $3 \%(w / v)$, gave the results shown. Organism NCIB 4940 gave similar results. Other experiments (Table 2) indicated that $9 \%(\mathrm{w} / \mathrm{v})$ was the optimum concentration of glucose and that variations in the peptone concentration in media containing 6 or $9 \%(w / v)$ glucose did not affect the yield of antibiotics significantly. 
Table 1. Effect of certain carbon sources on antibiotic production by Acetobacter acetigenum NCIB $\mathbf{8 1 3 2 .}$

The carbon sources were added to a basal medium $(\mathrm{pH} 7 \cdot 0)$ consisting of Difco yeastextract $(0.5 \%, w / v)$ and Evans's peptone $(2 \%, w / v)$ in distilled water. Activity is expressed as a percentage of that of the control; filtrates assayed at 7 days at dilution $1 / 12$.

$\begin{array}{cc} & \begin{array}{c}\text { Relative antibiotic } \\ \text { activity }\end{array} \\ \text { Growth medium } & (\%) \\ \text { Basal medium (control) } & 100 \\ \text { + maltose } & \mathbf{5 7} \\ \text { + glycerol } & \mathbf{8 9} \\ \text { + glucose } & \mathbf{1 5 7} \\ \text { +xylose } & \mathbf{1 6 4}\end{array}$

Table 2. Effects of concentration of glucose and of peptone on the yield of antibiotic produced by Acetobacter acetigenum NCIB 8132

Glucose and peptone were added to a basal medium ( $\mathrm{pH} 7 \cdot 0$ ) consisting of Difco yeastextract $(0.5 \%, w / v)$ in distilled water; filtrates assayed at 8 days at dilution $1 / 20$.

\begin{tabular}{|c|c|c|}
\hline \multicolumn{2}{|c|}{$\begin{array}{c}\text { Addition to } \\
\text { basal medium }\end{array}$} & \multirow{2}{*}{$\begin{array}{c}\text { Relative } \\
\text { yield } \\
\text { of antibiotic }\end{array}$} \\
\hline $\begin{array}{l}\text { Glucose } \\
(\%, w / v)\end{array}$ & $\begin{array}{l}\text { Peptone } \\
(\%, w / v)\end{array}$ & \\
\hline 6 & 3 (control) & 100 \\
\hline 6 & 6 & 104 \\
\hline 9 & 3 & 133 \\
\hline 9 & 6 & 136 \\
\hline 12 & $\mathbf{3}$ & 111 \\
\hline
\end{tabular}

Effect of calcium carbonate. Neither organism formed detectable antibiotic when grown in a medium containing glucose $(6 \%, \mathrm{w} / \mathrm{v})$, Difco yeast-extract $(0.5 \%, w / v)$ and Evans's peptone $(2 \%, w / v)$ in distilled water to which calcium carbonate $(2 \%, \mathrm{w} / \mathrm{v})$ had been added and the $\mathrm{pH}$ adjusted to 6.5 . In the same medium, but without calcium carbonate, organisms NCIB 8132 and NCIB 4940 gave $80 \%$ and $67 \%$ inhibition, respectively, at dilution $1 / 12$.

The course of cellulose formation and antibiotic production

Organism NCIB 8132 was grown in flasks of medium (pH 5.8) containing glucose $9 \%(\mathrm{w} / \mathrm{v})$, Difco yeast-extract $0.5 \%(\mathrm{w} / \mathrm{v})$ and Evans's peptone $3 \%(\mathrm{w} / \mathrm{v})$ in distilled water for different periods of time (1-11 days). The cellulose from duplicate flasks was washed in several changes of distilled water and then in methanol, and dried to constant weight at $80^{\circ}$. The filtrates were then assayed and the dilution at which the growth of the assay organism was inhibited by $\mathbf{5 0} \%$ was obtained. The results are shown graphically in Fig. 2. The inhibitory activity and the dry weight of cellulose increased with incubation time, the former reaching a maximum value $(50 \%$ inhibition at dilution $1 / 44$ ) at about 10 days. The $\mathrm{pH}$ of the culture medium decreased to 3.7 in about 6 days and remained constant thereafter. Filtrate from cultures 


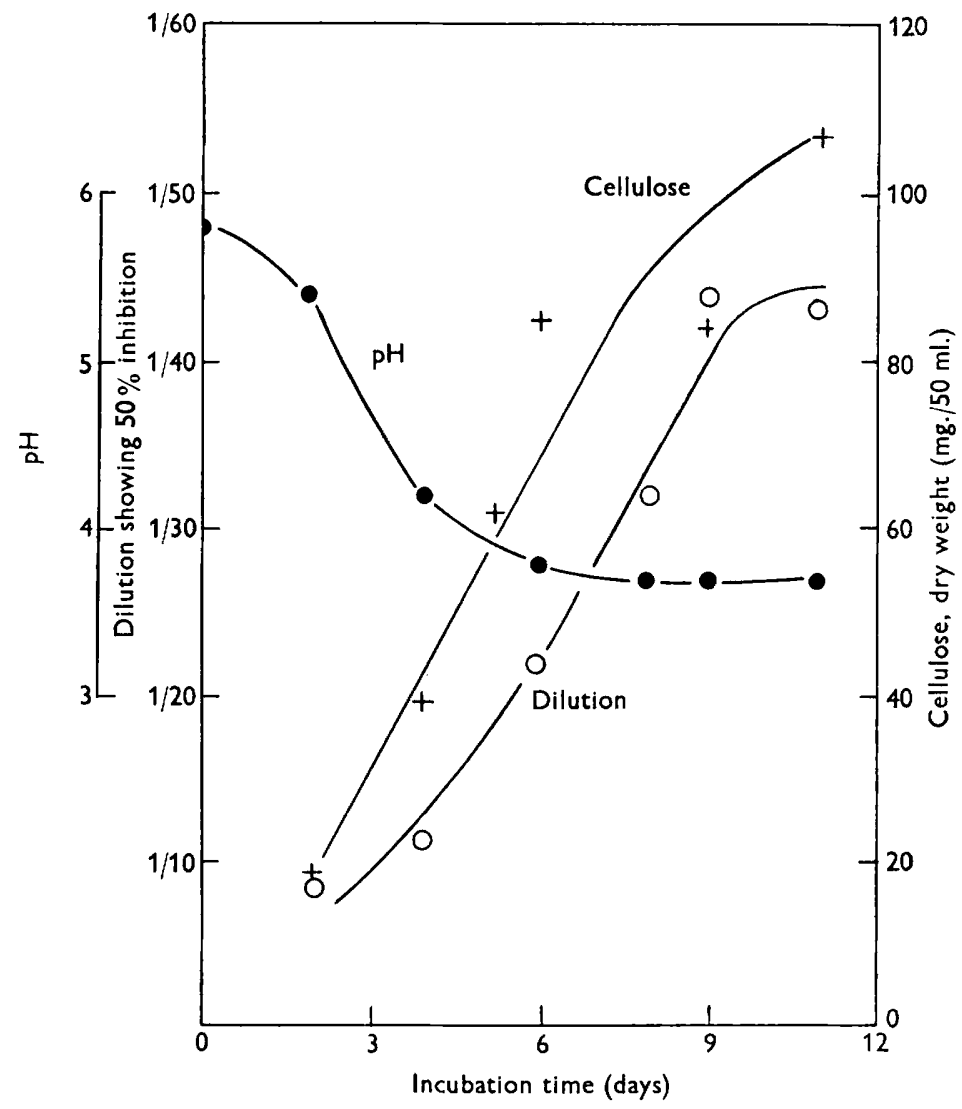

Fig. 2. Biochemical changes during growth of Acetobacter acetigenum, NCIB 8132 . Growth medium was glucose $(9 \%, w / v)$, Difco yeast-extract $(0.5 \%, w / v)$ and Evan's peptone, $(3 \%, w / v)$ in distilled water.

harvested at 10 days completely inhibited the growth of the assay organism at dilution $1 / 12$ but not at dilution $1 / 15$.

\section{Some properties of the antibiotics}

Most of the filtrates used in this part of the work were obtained from 8- to 10-day cultures grown in a medium $(\mathrm{pH} \mathrm{7 \cdot 0)}$ containing glucose $(6 \%, \mathrm{w} / \mathrm{v})$, Difco yeast-extract $(0.5 \%, \mathrm{w} / \mathrm{v})$ and Evans's peptone $(2 \%, \mathrm{w} / \mathrm{v})$, in distilled water.

Stability of the antibiotics at various $\mathrm{pH}$ values. The activity of filtrates from either test organism showed no significant loss after keeping at room temperature for $24 \mathrm{hr}$. at $\mathrm{pH}$ values of $3 \cdot 0$ or $6 \cdot 0$. At $\mathrm{pH} 10$, however, all activity was lost in $\mathbf{2}$ min. and, in fact, the filtrate stimulated the growth of the assay organism.

Effect of distillation of filtrate. Fifty $\mathrm{ml}$. of each culture filtrate $(\mathrm{pH} 6 \cdot \mathbf{0})$ were concentrated in vacuo to $c .10 \mathrm{ml}$., then the concentrate was made up to the 
original volume with distilled water. These solutions showed the same activity as the starting materials.

Effect of adsorbents and ion exchange resins. Samples of filtrate $(20 \mathrm{ml}$,, $\mathrm{pH} \mathrm{6.0)}$ were shaken with $0 \cdot 6 \mathrm{~g}$. calcium carbonate and after $30 \mathrm{~min}$. the suspension was centrifuged. Other samples were treated with the same weight of charcoal, but the charcoal was removed by filtration; a preliminary test showed that filtration alone did not affect the activity. Other $20 \mathrm{ml}$. portions of filtrate were treated with ZeoKarb $225(\mathbf{H})$ after which the resin was removed and the filtrate, whose $\mathrm{pH}$ had been reduced from 6.0 to 3.5 , was adjusted to $\mathrm{pH} 6 \cdot 0$. Another sample of filtrate was adjusted to $\mathrm{pH} 3.5$ before treatment with Amberlite IR-4B (OH), during which the $\mathrm{pH}$ rose to $6 \cdot 0$.

Table 3. Effect of certain adsorbents and ion-exchange resins on the inhibitory activity of culture filtrates

Residual activity is expressed as a percentage of the value obtained with untreated filtrate assayed at dilution $1 / 12$.

\begin{tabular}{lcc}
\multicolumn{1}{c}{ Filtrate treatment } & Activity of filtrate of \\
$\begin{array}{c}\text { Acetobacter } \\
\text { acetigenum, }\end{array}$ & $\begin{array}{c}\text { Bacterium } \\
\text { NCylinoides, }\end{array}$ \\
None (untreated) & 100 & 100 \\
Calcium carbonate & 100 & 81 \\
Charcoal & 109 & $13^{*}$ \\
Zeo-Karb 225 (H) (cation) & 102 & $54^{*}$ \\
Amberlite IR-4B (OH) (anion) & 79 & $45^{*}$
\end{tabular}

* Differs from the value for untreated filtrate at the $5 \%$ level of significance.

Table 4. Effect of solvent extraction of culture filtrates on inhibitory activity

Residual activity is expressed as a percentage of that of untreated filtrate assayed at dilution $1 / 12$.

\begin{tabular}{|c|c|c|}
\hline \multirow[b]{2}{*}{ Solvent } & \multicolumn{2}{|c|}{ Residual activity of filtrate of } \\
\hline & $\begin{array}{l}\text { Acetobacter } \\
\text { acetigenum, } \\
\text { NCIB } 8132\end{array}$ & $\begin{array}{c}\text { Bacterium } \\
\text { xylinoides, } \\
\text { NCIB } 4940\end{array}$ \\
\hline None (untreated) & 100 & 100 \\
\hline Benzene & 120 & 24* \\
\hline$n$-Butanol & $70 *$ & $60^{*}$ \\
\hline Chloroform & $71^{*}$ & $48 *$ \\
\hline Diethyl ether & 100 & $26 *$ \\
\hline Ethyl acetate & 95 & $54 *$ \\
\hline Methyl ethyl ketone & $60^{*}$ & $42 *$ \\
\hline Methyl iso-butyl ketone & 91 & - \\
\hline
\end{tabular}

* Differs from the value for untreated filtrate at the $5 \%$ level of significance.

The results (Table 3) indicate that the inhibitory agent from organism NCIB 8132 was not significantly adsorbed, whereas that of organism NCIB 4940 was removed partially with charcoal and ion-exchange resins, but not by treatment with calcium carbonate. 
Solvent extraction. Samples of filtrate ( $\mathrm{pH} \mathrm{3.0)}$ were shaken in a separatory funnel with an equal volume of the selected solvent. The aqueous phase was freed from solvent by vacuum distillation, adjusted to $\mathrm{pH} 6 \cdot 0$, made up to the original volume with distilled water and assayed. The results (Table 4) show that in this respect, too, the antibacterial activity from the two organisms behaves differently. In other experiments the antibiotic from organism NCIB 8132 was not extracted at $\mathrm{pH} 6 \cdot 0$ with benzene, $n$-butanol, chloroform or ethyl acetate.

Effect of proteolytic enzyme. When $1 \mathrm{ml}$. of a $2 \%(\mathrm{w} / \mathrm{v})$ solution of Evans's Pepsinum in $0.001 \mathrm{~N}$-hydrochloric acid was added to $10 \mathrm{ml}$. samples of filtrate $\left(\mathrm{pH} \mathrm{3.0)}\right.$ and the mixtures incubated at $30^{\circ}$ for $24 \mathrm{hr}$., the titres remained the same as that of a control made up with boiled enzyme. Experiments with gelatin showed that the enzyme preparation was active.

\section{DISCUSSION}

In previous studies (Steel \& Walker, 1957b) with organism NCIB 8132 it was found that filtrate obtained from cultures grown in GYE medium inhibited the growth of the assay organism by $50 \%$ at dilution $1 / 3$. In the present work the highest filtrate dilution producing a similar amount of inhibition was about $1 / 44$ (Fig. 2), indicating an increase in yield of about 15-fold.

The antibiotic yield from both organisms (NCIB 8132 and NCIB 4940) was independent of the nitrogen source but was influenced by the type and amount of the carbon source available. Both antibiotics were extremely labile to alkali. That the two inhibitors were not identical was indicated by the difference in slopes of the assay plots shown in Fig. 1 (although these are not strictly comparable because different media were used), and by differences in behaviour towards adsorbents and solvents (Tables 3 and 4).

The failure of cultures containing calcium carbonate to produce antibiotics was unexpected. This might have been caused by the diversion of carbohydrate metabolism away from the direction of the antibiotic towards the formation of calcium salts of organic acids, e.g. gluconic, ketogluconic (see Kulka \& Walker, 1954) or perhaps the antibiotic was adsorbed on the calcium carbonate during the rather long period of incubation (8 days). Further study of these substances is planned.

One of us (R.S.) acknowledges the receipt of an Imperial Chemical Industries Research Fellowship. The authors are grateful to Professor D. D. Woods for his opinion on some aspects of this work.

\section{REFERENCES}

BrownleE, K. A. (1949). Industrial Experimentation, 4th ed. London: $\mathrm{He}_{\mathbf{T}}$ Majesty's Stationery Office.

Clayton, J. C., Hems, B. A., Robinson, F. A., Andrews, R. D. \& Hunwicke, R. F.(1944). Preparation of penicillin. Improved method of isolation. Biochem.J. 38, 452 . 
Kulka, D. \& Walker, T. K. (1954). The ketogenic activities of Acetobacter species in a glucose medium. Arch. Biochem. Biophys. 50, 169.

Steel, R. \& WALker, T. K. $(1957 a)$. Celluloseless mutants of certain Acetobacter species. J. gen. Microbiol. 17, 12.

Steel, R. \& Walker, T. K. (1957b). A highly specific growth-inhibitory factor produced by certain Acetobacter species. Nature, Lond. 180, 201.

Tosic, J. \& WALKer, T. K. (1946). Procedure for the characterisation of the acetic acid bacteria. Chem. \& Ind. (Rev.) 65, 104.

(Received 20 September 1957) 